\title{
Convective rainfall in a dry climate: relations with synoptic systems and flash-flood generation in the Dead Sea region
}

\author{
Idit Belachsen ${ }^{1,2}$, Francesco Marra ${ }^{2}$, Nadav Peleg $^{3}$, and Efrat Morin ${ }^{2}$ \\ ${ }^{1}$ Hydrology and Water Resources Program, Hebrew University of Jerusalem, 91904, Israel \\ ${ }^{2}$ Institute of Earth Sciences, Hebrew University of Jerusalem, 91904, Israel \\ ${ }^{3}$ Institute of Environmental Engineering, Hydrology and Water Resources Management, ETH Zurich, Switzerland \\ Correspondence to: Idit Belachsen (idit.belachsen@mail.huji.ac.il) and Efrat Morin (efrat.morin@mail.huji.ac.il)
}

Received: 19 April 2017 - Discussion started: 2 May 2017

Revised: 10 August 2017 - Accepted: 18 August 2017 - Published: 12 October 2017

\begin{abstract}
Spatiotemporal patterns of rainfall are important characteristics that influence runoff generation and flashflood magnitude and require high-resolution measurements to be adequately represented. This need is further emphasized in arid climates, where rainfall is scarce and highly variable. In this study, 24 years of corrected and gaugeadjusted radar rainfall estimates are used to (i) identify the spatial structure and dynamics of convective rain cells in a dry climate region in the Eastern Mediterranean, (ii) to determine their climatology, and (iii) to understand their relation with the governing synoptic systems and with flashflood generation. Rain cells are extracted using a segmentation method and a tracking algorithm, and are clustered into three synoptic patterns according to atmospheric variables from the ERA-Interim reanalysis. On average, the cells are about $90 \mathrm{~km}^{2}$ in size, move $13 \mathrm{~m} \mathrm{~s}^{-1}$ from west to east, and live for $18 \mathrm{~min}$. The Cyprus low accounts for $30 \%$ of the events, the low to the east of the study region for $44 \%$, and the Active Red Sea Trough for $26 \%$. The Active Red Sea Trough produces shorter rain events composed of rain cells with higher rain intensities, longer lifetime, smaller area, and lower velocities. The area of rain cells is positively correlated with topographic height. The number of cells is negatively correlated with the distance from the shoreline. Rain-cell intensity is negatively correlated with mean annual precipitation. Flash-flood-related events are dominated by rain cells of large size, low velocity, and long lifetime that move downstream with the main axis of the catchments. These results can be further used for stochastic simulations of convective rain storms and serve as input for hydrological models and for flash-flood nowcasting systems.
\end{abstract}

\section{Introduction}

A flash flood is a rapid runoff response of a catchment to intense precipitation. Owing to their short response time and high intensity, flash floods are difficult to predict and result in economic damages and casualties (Borga et al., 2011). In fact, they are among the most dangerous meteorological hazards affecting the Mediterranean countries (Llasat et al., 2010; Tarolli et al., 2012). Many factors contribute to flashflood generation, such as rainfall conditions (e.g., amount, intensity, and spatial and temporal distribution), catchment morphological properties (e.g., slope and surface cover), and hydrological preconditions (e.g., soil saturation). The magnitude of a flash flood is determined by the interactions between these factors (Borga et al., 2014; Nied et al., 2014; Smith et al., 2002; Wright et al., 2014).

In particular, rainfall spatial and temporal variability is a key factor in runoff response prediction (Bahat et al., 2009; Faurés et al., 1995; Morin et al., 2006; Morin and Yakir, 2014; Rozalis et al., 2010; Yakir and Morin, 2011; Yang et al., 2016a). Rozalis et al. (2010) found great sensitivity in flash-flood generation and magnitude to the intra-storm rain intensity distribution. Andréassian et al. (2004) and Zoccatelli et al. (2010) reported that neglecting rainfall spatial variability resulted in a considerable degradation of the modeling results. Yakir and Morin (2011) observed high sensitivity in the response of an arid catchment to location, direction, and velocity of the convective storm.

The need to account for rainfall variability is accentuated in arid and semi-arid regions, where rainfall is often of a convective nature and characterized by extremely variable, high-intensity, short-duration events (Goodrich et al., 1995; 

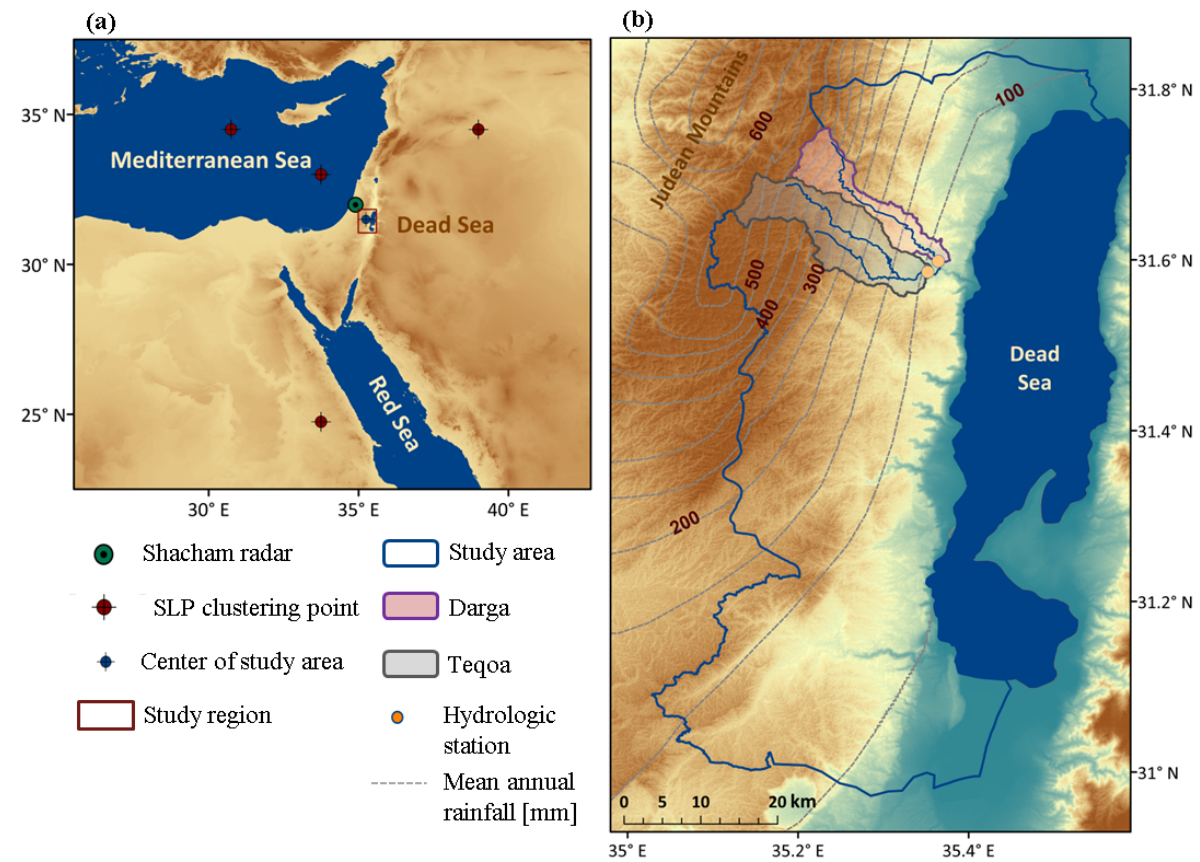

Figure 1. Map of the Eastern Mediterranean area presenting radar location and coordinates used to derive sea level pressure (SLP) differences for synoptic classification (a). A map of the study area with the Darga and Teqoa catchments (b). Isohyets over the study region represent long-term (30 years, 1980-2010) mean annual rainfall (mm).

Syed et al., 2003; Segond et al., 2007). Although antecedent soil-moisture conditions are known to play a role in runoff generation, studies conducted in semi-arid and arid areas ascribed them only a minor influence on flood response, due to low infiltration capacities of the ground, high evaporation rates (Ries et al., 2017; Syed et al., 2003; Yair and Lavee, 1985), and long dry spells between rainfall events (Saaroni et al., 2014). Hence, high-resolutions in space and time, and over large areas, are required to adequately represent rainfall spatio-temporal distributions. These can be best achieved by remote sensing tools such as weather radars (e.g., Barnolas et al., 2010; Berne and Krajewski, 2013; Karklinsky and Morin, 2006; Krajewski and Smith, 2002; Peleg and Morin, 2012).

The spatial distribution of rainfall in convective environments is often examined by focusing on the properties of the convective rain cells (abbreviated hereafter as rain cells), which can be directly derived by exploiting the full threedimensional structure of the cells (Dixon and Wiener, 1993; Johnson et al., 1998; Steiner et al., 1995) or, more commonly, extracting the convective two-dimensional segments from radar data (Barnolas et al., 2010; Cox and Isham, 1988; Féral, 2003; Féral et al., 2000; von Hardenberg, 2003; Karklinsky and Morin, 2006; Northrop, 1997). A widely used approach requiring only two-dimensional information is to define them as areas in which the rain intensity exceeds a certain threshold. This simplified representation of the rain field allows focusing on the high flash-flood generating potential portion of the storm, and is used in synthetic rainfall generators and hydrological models (e.g., Morin et al., 2006; Peleg and Morin, 2012; Wheater et al., 2000; Yakir and Morin, 2011).

Rain cells can be represented by fitting an ellipse around the local rain maxima in a radar image (Féral et al., 2000; Karklinsky and Morin, 2006) and geometrical properties of the cells such as area, axes length, orientation angle, and maximal intensity can then be derived. Some studies accounted for rain-cell dynamics by monitoring their progress over time with tracking algorithms (e.g., Dixon and Wiener, 1993; Johnson et al., 1998; Kyznarová and Novák, 2009; Peleg and Morin, 2012; Rinehart and Garvey, 1978). This allowed the derivation of additional parameters such as raincell lifetime, velocity, and direction of movement.

The atmospheric conditions generating a rainfall event are expected to influence the properties of rain cells and, consequently, the rainfall-catchment interactions and the runoff response. The objective of this study is to quantify the properties of rain cells originated within different synoptic systems in an arid climate region and to understand the rain cellcatchment interactions with the generation of flash floods. Specific questions motivating this study include the following. (i) What are the property distributions of convective rain cells in dry environments? (ii) How do they vary between different synoptic systems? (iii) How do rain-cell characteristics change within the study region? (iv) What are the cell properties that dominate the formation and magnitude of flash floods? These questions are examined through a statistical 
Table 1. Morphological and hydrological characteristics of the Darga and Teqoa catchments.

\begin{tabular}{lrr}
\hline Catchment property & Darga & Teqoa \\
\hline Area $\left(\mathrm{km}^{2}\right)$ & 73 & 140 \\
Height range (m above sea level) & -19 to +813 & -20 to +992 \\
Mean channel gradient $(-)$ & 0.027 & 0.029 \\
Mean hillslope gradient (-) & 0.114 & 0.135 \\
Percentage of desert soils (\%) & 42 & 37 \\
Maximal observed peak discharge $\left(\mathrm{m}^{3} \mathrm{~s}^{-1}\right)^{*}$ & 61.2 & 158.5 \\
Average number of flow events per year* & 1.96 & 2.13 \\
Threshold discharge value (according to Shamir et al., 2013) $\left(\mathrm{m}^{3} \mathrm{~s}^{-1}\right)$ & 0.25 & 2 \\
\hline
\end{tabular}

* Data record of hydrological years 1990/1991-2014/2015.

analysis of rain cells derived from 24 years of weather radar data over the western tributaries of the Dead Sea and flash flood data from two catchments within this region (Fig. 1).

The paper is organized as follows. The study area and data are described in Sect. 2. Section 3 analyzes the relations between the properties of the rain cells and the governing synoptic system. Section 4 presents the impact of rain-cell properties on flash-flood generation. The results of the study are discussed in Sect. 5. Section 6 reports the concluding remarks.

\section{Regional background and data}

This study focuses on the western tributaries of the Dead Sea in the Eastern Mediterranean (EM, Fig. 1) that drain from the Judean Mountains water divide (600-1000 m a.s.l.) towards the Dead Sea (currently $430 \mathrm{~m}$ below sea level). The study area is of $3315 \mathrm{~km}^{2}(\sim 50 \mathrm{~km}$ west to east and $\sim 80 \mathrm{~km}$ north to south).

\subsection{Climate}

The area is dominated by semi-arid and arid climates except for the northwestern part that is governed by a Mediterranean climate (Greenbaum et al., 2006). Mean annual precipitation shows a steep gradient from over $500 \mathrm{~mm}$ in the northwestern portion of the area to about $150 \mathrm{~mm}$ and even less than $50 \mathrm{~mm}$ in the northeastern and southern parts, respectively (Fig. 1b). The west-to-east gradient is due to the rain shadow effect caused by the Judean Mountains and by the low topography of the Dead Sea valley. The north-to-south gradient is related to the distance from the shoreline and from the main tracks of Mediterranean storms. Rainfall occurs from October to May, with no rain during summer (Goldreich, 2003). Intensities and duration of extreme events differ dramatically within the study area, with the relative frequency of high rainfall intensities increasing as the mean annual precipitation decreases (Marra et al., 2017; Marra and Morin, 2015; Morin et al., 2009; Sharon and Kutiel, 1986).
Most intense rainfall episodes over the study area, and the EM in general, are associated with the cold fronts of mid-latitude lows: the Cyprus low - a Mediterranean low located around Cyprus, and the Syrian low - a well-developed Mediterranean low located over Syria (Dayan et al., 2015; Dayan and Morin, 2006; Goldreich, 2003; Kahana et al., 2002). The region is also affected by more localized convective showers associated with the Active Red Sea trough (ARST), a surface low-pressure trough extending from eastern Africa along the Red Sea towards the Middle East in its active phase (Ashbel, 1938). The ARST is more frequent during the transition seasons and its contribution to rainfall and flash floods in the EM decreases going north (Kahana et al., 2002; Dayan and Morin, 2006). According to Kahana et al. (2002), the ARST accounts for most of the major floods over the arid catchments in the south of the study area, followed by the Syrian low. Some rare events of relatively widespread rainfall leading to flash floods in the region are associated with the subtropical jet and the conveying of air moisture of tropical origin over Africa to the Eastern Mediterranean; a system often referred to as tropical plume (Dayan and Morin, 2006; Kahana et al., 2002; Tubi and Dayan, 2014; Ziv, 2001)

\subsection{Hydrology}

Two side-by-side gauged catchments, located in the northern part of the study area (Fig. 1b), are chosen for the analysis due to the availability of long and concurrent records of water discharge and radar data; these are the Darga $\left(73 \mathrm{~km}^{2}\right)$ and Teqoa $\left(140 \mathrm{~km}^{2}\right)$. These catchments have ephemeral dry channels, and flash-flood events occur on average twice a year (Table 1). The surface is characterized by large areas of bare rock, shallow soils of low permeability, and sparse vegetation.

Water discharge data were obtained from the Israel Hydrological Service for the 24 hydrological years (October to September) 1990/1991-2013/2014. In order to avoid analysis of low flows, events with peak discharges lower than $0.25 \mathrm{~m}^{3} \mathrm{~s}^{-1}$ for Darga and $2 \mathrm{~m}^{3} \mathrm{~s}^{-1}$ for Teqoa were excluded from the analysis. These thresholds were based on Shamir 


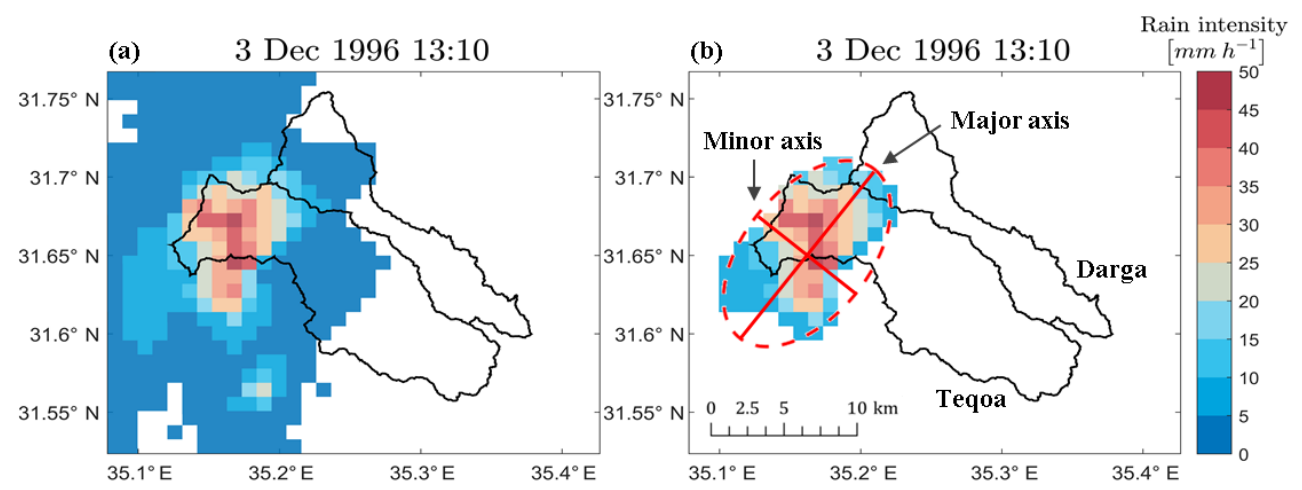

Figure 2. An example of a rain-cell derivation for 3 December 1996, 13:10 (UTC) over the Darga and Teqoa catchments. Radar rainfall for the examined time (a), a segment of an identified rain cell and its fitted ellipse (b). The spatial properties of the presented cell are the following: area, $90 \mathrm{~km}^{2}$; orientation, $51^{\circ}$; major axis length, $15 \mathrm{~km}$; minor axis length, $9 \mathrm{~km}$; ellipticity, 0.58 ; max rainfall intensity, $47 \mathrm{~mm} \mathrm{~h}^{-1}$; and mean rainfall intensity, $20 \mathrm{~mm} \mathrm{~h}^{-1}$.

et al. (2013) who developed a method for determining minimal flash-flood thresholds for arid regions using geomorphic indexes.

\subsection{Weather radar}

Rainfall data used for the research are based on the Shacham weather radar, a C-band non-Doppler instrument, located within the Ben-Gurion international airport (Israel), 50$125 \mathrm{~km}$ northwest of the study area (Fig. 1). The observation geometry of the radar is characterized by a spatial polar resolution of $1.4^{\circ} \times 1 \mathrm{~km}$ and a temporal resolution of about 5 min per volume scan. Its archived data record is of 24 hydrological years 1990/1991-2013/2014. Such a long record represents a clear advantage for climatological and hydrological studies in an arid region and data from this radar were fruitfully used for research in many studies so far (Karklinsky and Morin, 2006; Marra et al., 2017; Marra and Morin, 2015; Morin et al., 2001; Morin and Gabella, 2007; Morin and Yakir, 2014; Peleg et al., 2016, 2013, 2015a, b; Peleg and Morin, 2012; Rozalis et al., 2010). An extensive description of the quantitative radar precipitation estimation and of its assessment is provided in Marra and Morin (2015). The distance from the radar increases going south and east in the study area, so that the instrument samples higher atmospheric levels (sampling elevation between 1000 and $4500 \mathrm{~m}$ ). The radar data are corrected taking into account the vertical profile of reflectivity, but overshooting of precipitation in the study area is possible. However, this problem is expected to be negligible for this study, in which vertically developed systems, such as the convective cells, are examined.

\section{Rain cell characterization}

\subsection{Rain cell identification and tracking}

The identification of rain cells is done by partitioning each radar image into segments, and is followed by a cell tracking algorithm (Peleg and Morin, 2012). Rain cells are defined as connected radar pixels with the following: (i) more than $5 \mathrm{~mm} \mathrm{~h}^{-1}$ rain intensity, (ii) at least one peak exceeding $10 \mathrm{~mm} \mathrm{~h}^{-1}$, and (iii) an area larger than $9 \mathrm{~km}^{2}$. These thresholds were suggested and used in previous studies (e.g., von Hardenberg, 2003; Morin et al., 2006; Syed et al., 2003) and allow focusing on the convective part of the rain without excluding moderate rainfall intensities that could be relevant for the flood generation. It should be noted that the selection of the thresholds can affect some of the derived properties (e.g., cell area and mean areal rain intensity), but it should not affect the comparison of these properties between different groups of cells.

The spatial properties extracted from each segment are the following: area $\left(\mathrm{km}^{2}\right)$, length of the major and minor axes of the ellipse fitted to the segment $(\mathrm{km})$, ellipse center location, ellipticity (minor-to-major axis ratio), orientation (angle of the major axis in degrees relative to the west-east orientation, positive values are counter-clockwise), maximum rain intensity $\left(\mathrm{mm} \mathrm{h}^{-1}\right)$, and mean areal intensity (i.e., the mean intensity over the area of the segment, in $\mathrm{mm} \mathrm{h}^{-1}$ ). Figure 2 presents an example of one radar image and a derived rain cell with its spatial properties.

The cell tracking algorithm links rain cells in consecutive images and allows characterizing of the rain-cell lifetime and average advection (velocity and direction). The algorithm, developed by Kyznarová and Novák (2009) and modified by Peleg and Morin (2012), is based on Pearson's correlation between shifted successive images. The term "lifetime" relates to the length of the individual cell's life, while "duration" to the length of the rain event. Frequencies of different tracking 

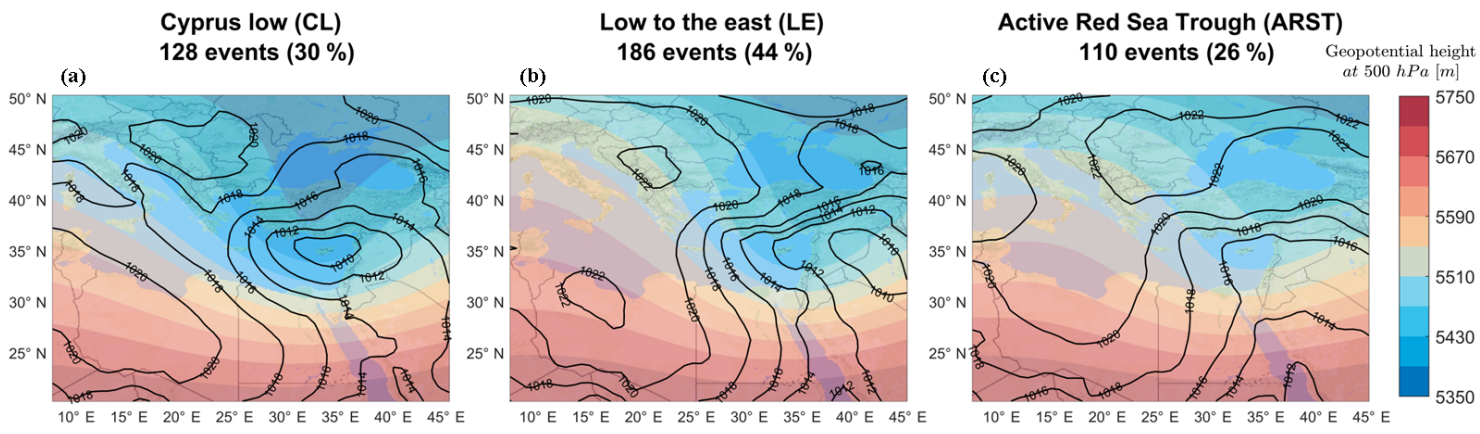

Figure 3. Average SLP (hPa, black contour lines) and geopotential height at $500 \mathrm{hPa}$ (m, in color) for each cluster; (a) Cyprus low, (b) low to the east, and (c) Active Red Sea Trough (ARST).

categories during the cell's full life cycle (i.e., frequency of splits and merges) were left out of the analysis as no added value to the presented results was given. A total of 10447 rain cells (composing 2632 tracks) were derived. The rain record was divided into 424 rain events, defined as separated by dry spells longer than $6 \mathrm{~h}$. This allowed associating each rain cell to the governing synoptic system of the rain event. Rain events for which less than $80 \%$ of the radar scans were available have been removed.

\subsection{Synoptic classification}

Rain events were classified into synoptic types using cluster analysis. The clustering was aimed at relying mainly on the sea level pressure (SLP) map, the most commonly used map for synoptic classification in the EM (Alpert et al., 2004; Dayan et al., 2012; Kahana et al., 2002; Zangvil et al., 2003) and in other places in the world (Cannon et al., 2002; Hewitson and Crane, 2002). In addition, surface temperature was used to distinguish between an ARST and a cold Mediterranean low, since the former is usually initiated by thermal instability caused by differential heating between the surface (where a warm advection from the southeast takes place) and the upper atmospheric levels (Dayan et al., 2001). Other atmospheric variables (e.g., specific humidity at $700 \mathrm{hPa}$ and temperature at $850 \mathrm{hPa}$ ) were tested and found to have a negligible influence on the clustering. Each rain event was linked to the ERA-Interim global reanalysis atmospheric variables (Dee et al., 2011) - SLP and near-surface (1000 hPa) air temperature, obtained for the time closest to the rain event's center of mass (chosen out of Era-Interim 4 times daily available times - 00:00, 06:00, 12:00, 18:00 UTC).

A hierarchical agglomerative clustering technique using Ward's criterion was applied based on the following: (i) location of the minimum SLP within the EM region (25.5$42.75^{\circ} \mathrm{E}$ and $22.5-37.5^{\circ} \mathrm{N}$ ); (ii) north-south SLP difference between two points $-\left(33.75^{\circ} \mathrm{E}, 33^{\circ} \mathrm{N}\right)$ and $\left(33.75^{\circ} \mathrm{E}\right.$, $24.75^{\circ} \mathrm{N}$ ); (iii) west-east SLP difference between two points - $\left(30.75^{\circ} \mathrm{E}, 34.5^{\circ} \mathrm{N}\right)$ and $\left(39^{\circ} \mathrm{E}, 34.5^{\circ} \mathrm{N}\right)$; and (iv) nearsurface temperature at the grid point closest to the center of the study area $\left(35.25^{\circ} \mathrm{E}, 31.5^{\circ} \mathrm{N}\right)$. All the mentioned points are presented in Fig. 1a.

The rain events were found to be best described by three clusters (Fig. 3). The first cluster (128 events, Fig. 3a) describes a Mediterranean low located west of the shoreline, and is associated with a Cyprus low (CL). The second cluster (186 events, Fig. 3b) describes a low to the east (LE) and could be associated with a Syrian low, or with any other Mediterranean low settled east of the study area. The third cluster (110 events, Fig. 3c) describes a surface trough extending from the south and is associated with an ARST. The radar rain record did not include tropical plume events and therefore this synoptic type is not considered in the present analysis.

On average, both Mediterranean lows (Fig. 3a and b) are accompanied by a pronounced $500 \mathrm{hPa}$ trough extending from eastern Europe towards the EM, with an axis orientation of north-south to northeast-southwest. Besides the known effect of an upper level trough on the intensification of the low on the surface (Ahrens, 2003), under such atmospheric conditions the northwesterly flow is enriched with moisture from the sea, increasing the probability of rainfall in the southern EM (Zangvil and Druian, 1990; Ziv et al., 2006). The upper trough of the ARST (Fig. 3c) is shallower and has a similar axis orientation.

Validation of the clustering results was done according to expert examinations. Maps displaying contour lines of SLP and wind directions at $850 \mathrm{hPa}$ for 30 randomly chosen events were given to three experts to evaluate. The experts were asked to choose the synoptic system that best describes a given map out of four possible options: CL, LE, ARST, and "none of the above". Mismatches between the three experts' classifications and the automated clustering were then counted in relation to the extent of disagreement between the experts. For 19 maps there was an agreement between the experts and the automated procedure. Three out of 30 maps were agreed on between all experts but were classified differently from the automated procedure, resulting in a $10 \%$ classification error. For 8 maps there was no agreement among the experts, resulting in 7 maps with matches between only 


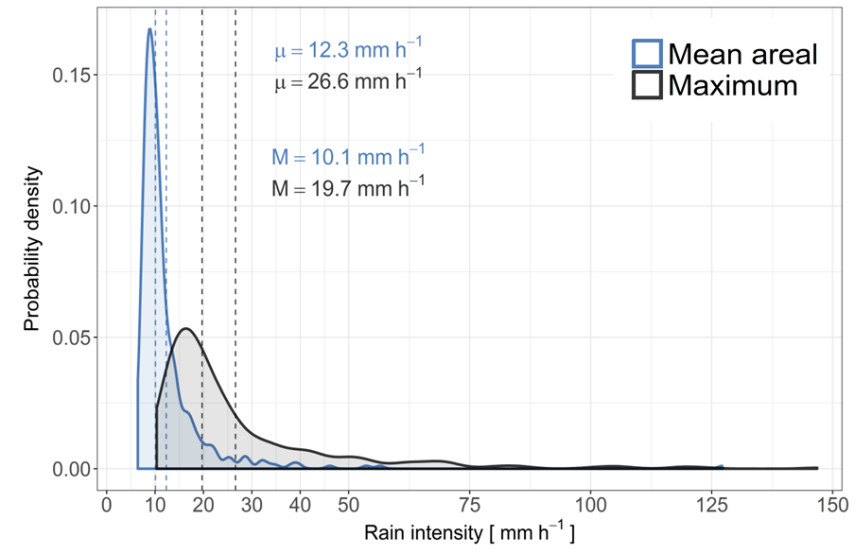

Figure 4. Empirical probability density functions of mean areal (blue) and maximum (black) rain intensities of rain cells over the Dead Sea (smoothed). $\mu$ represents the mean and $M$ represents the median.

some of the experts and the automated procedure and 1 map with no matches.

\subsection{Spatial and temporal rain-cell characteristics}

In this section, the differences between properties of rain cells originated by different synoptic systems are analyzed. Event properties and average spatial and temporal characteristics of rain cells are presented in Table 2. The use of averaged cell characteristics allows for neutralizing the dependency between individual rain cells of the same event and is crucial for the statistical comparison between the properties of cells generated by different synoptic systems. From this point on, unless stated otherwise, all values of rain-cell properties mentioned are the average value during the event. Advection direction is defined following the meteorological standard, i.e., it represents the direction of the origin (e.g., direction of $270^{\circ}$ represents a movement from west to east).

The average duration of all rain events is $5.4 \mathrm{~h}$. On average, the rain cells are $92 \mathrm{~km}^{2}$ in area, advecting from west to east $\left(274^{\circ}\right)$ at a velocity of $12.8 \mathrm{~m} \mathrm{~s}^{-1}$ and living $18.1 \mathrm{~min}$. Ellipticity of cells is 0.57 (minor to major axis length ratio of $3: 5)$. The major axis is close to alignment $\left(18^{\circ}\right)$ with their direction of movement. Similar values of ellipticity and orientation were found in previous studies conducted close to the study area (Karklinsky and Morin, 2006; Morin et al., 2006; Peleg and Morin, 2012; Yakir and Morin, 2011), and in other regions such as Catalonia and France (Barnolas et al., 2010; Féral et al., 2000). The empirical probability density functions of the cells' rain intensities are shown in Fig. 4. The mean areal and maximal rain intensities are 12.3 and $26.6 \mathrm{~mm} \mathrm{~h}^{-1}$, respectively, and both functions are positively skewed (skew coefficients of 7.4 and 2.7 , respectively) as a result of extreme rainfall events.

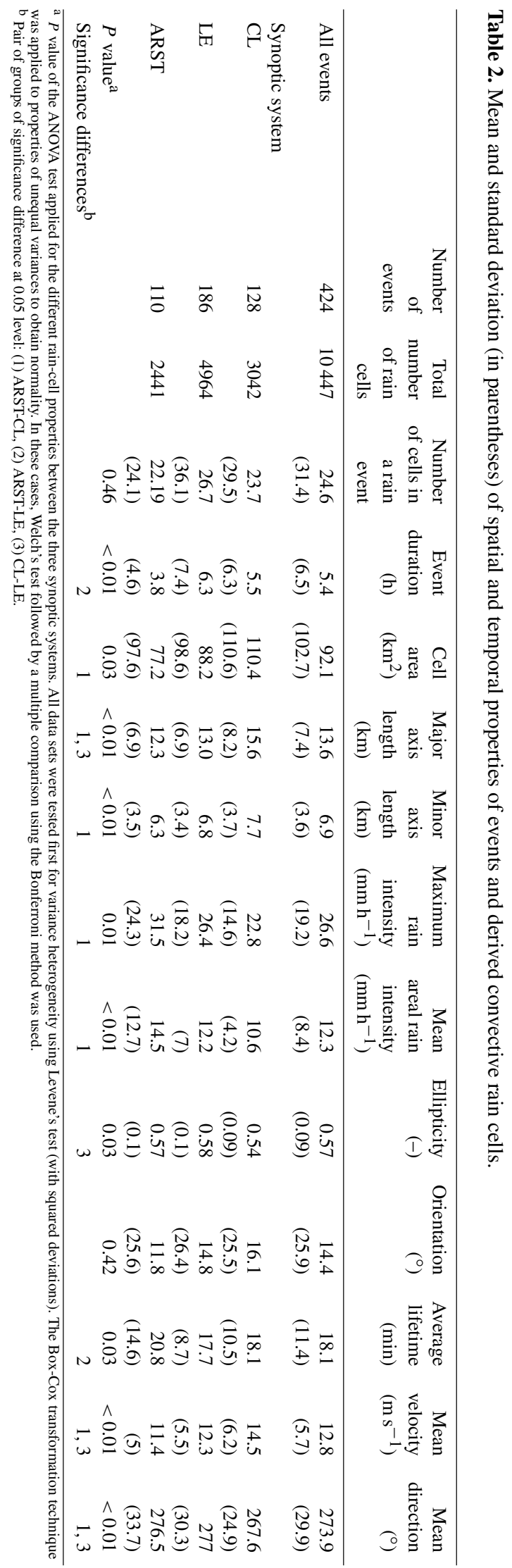



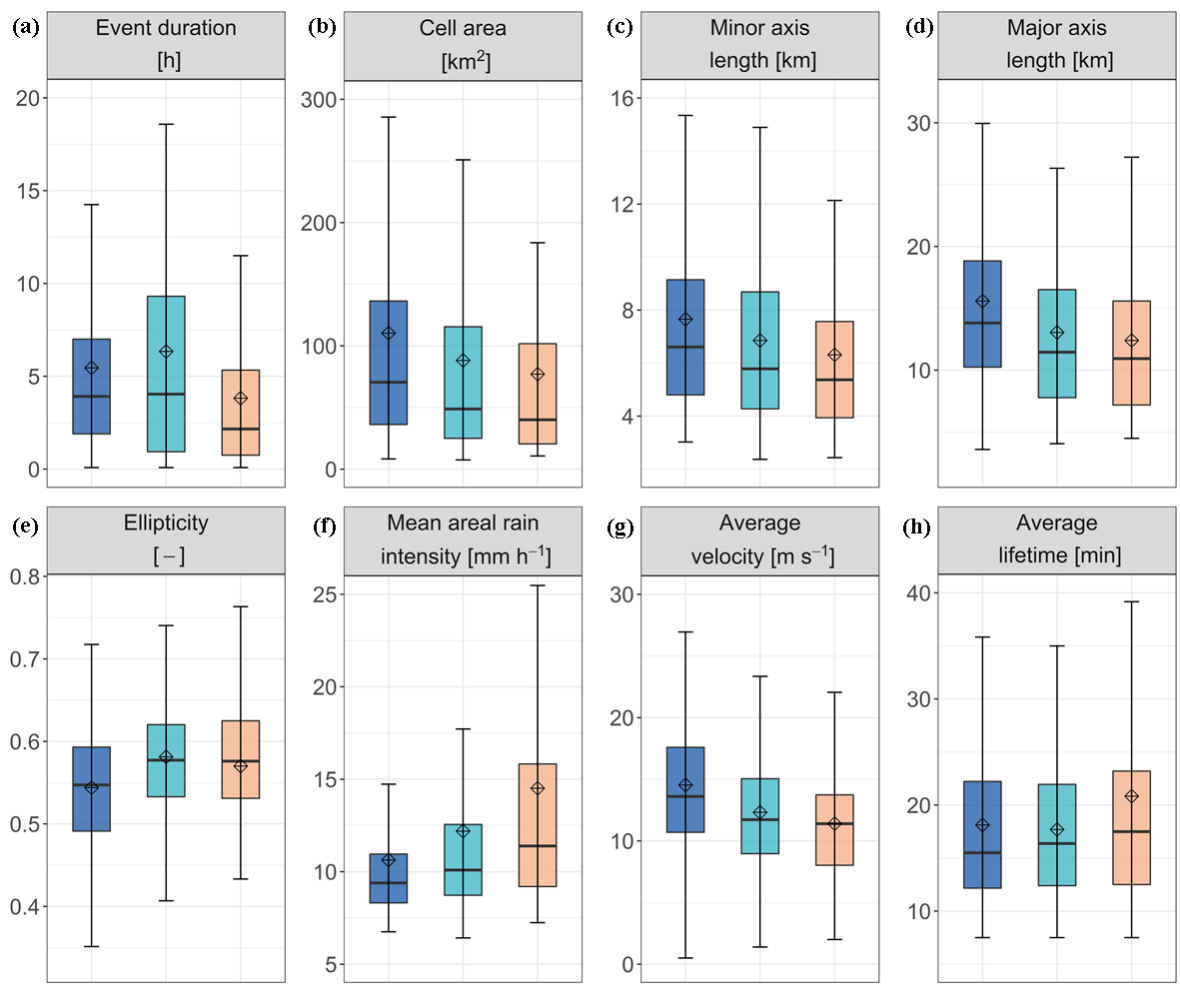

追 CL 追LE 白 $\mathrm{ARST}$

Figure 5. Comparison of rain-cell properties (averaged for each rain event) of the three synoptic systems: CL (dark blue), LE (light blue) and ARST (orange); (a) average event duration (h), (b) cell area $\left(\mathrm{km}^{2}\right),(\mathbf{c})$ minor axis length $(\mathrm{km}),(\mathbf{d})$ major axis length (km), (e) ellipticity (-), (f) mean areal rain intensity $\left(\mathrm{mm} \mathrm{h}^{-1}\right)$, (g) average velocity $\left(\mathrm{m} \mathrm{s}^{-1}\right)$, and (h) average lifetime (min). The black line in each boxplot marks the median, black diamond the mean, boxes lower and upper borders mark the 25 and $75 \%$ quartiles, respectively, and the whiskers mark minimum and maximum values unless these values exceed 1.5 · IQR (inter quartile range - the distance between lower and upper quartiles). Outliers are not shown. See Table 2 for numerical values of the mean and standard deviation.

\subsubsection{Effect of synoptic system}

Spatial and temporal properties of rain cells originated by different synoptic systems are compared (Table 2 and Figs. 5 and 6) using one-way analysis of variance (ANOVA) followed by a multiple pairwise comparison of the three groups' means using Tukey's honest significant difference criterion. Statistically significant differences have been found and are highlighted in Table 2.

The LE rain events are characterized by the highest average duration of all synoptic systems (6.3 h compared to 5.5 and $3.8 \mathrm{~h}$ of the CL and ARST events, respectively, Fig. 5a). The area of the ARST rain cells was found to be smaller than the area of the Mediterranean lows $\left(76 \mathrm{~km}^{2}\right.$ compared to 110 and $87 \mathrm{~km}^{2}$ of the CL and LE, respectively, Fig. 5b), but cells were found to live longer than cells in other synoptic systems (20.8 min compared to 18.1 and $17.7 \mathrm{~min}$ of the $\mathrm{CL}$ and LE, respectively, Fig. 5h). Moreover, ARST rain cells' mean areal rain intensity $\left(14.5 \mathrm{~mm} \mathrm{~h}^{-1}\right)$ and maximal rain intensity $\left(31.5 \mathrm{~mm} \mathrm{~h}^{-1}\right.$, Table 2$)$ were found to be higher than both CL intensities (10.6 and $22.8 \mathrm{~mm} \mathrm{~h}^{-1}$ ) and LE in- tensities (12.2 and $26.4 \mathrm{~mm} \mathrm{~h}^{-1}$ ) and these events have the highest variability in mean areal rain intensities (Fig. 5f).

The rain cells generally preserve the same orientation for all three synoptic types, but their shape is different: CL cells are characterized by lower ellipticity ( 0.54 compared to 0.58 and 0.57 of the LE and ARST, respectively). General mean orientation is west to east with a $12-16^{\circ}$ counterclockwise tilt from the west-east axis (Table 2). The CL events are characterized by rain cells generally moving from west to east (268 ${ }^{\circ}$, Fig. 6a), whereas the LE and ARST events are characterized by a slightly stronger northwestern component (about $277^{\circ}$, Fig. $6 \mathrm{~b}$ and c). In the ARST case, the direction distribution is bimodal, with cells originating from west-southwest and west-northwest (Fig. 6c). ARST events are characterized by lower average velocities $\left(11.4 \mathrm{~m} \mathrm{~s}^{-1}\right.$ compared to 14.5 and $12.3 \mathrm{~m} \mathrm{~s}^{-1}$ of the CL and LE, respectively, Fig. $\left.5 \mathrm{~g}\right)$.

Significant differences $(P$ value $<0.05)$ are found between the following: (i) ARST and CL cell areas, minor axis length, maximum rain intensities, and mean areal rain intensities; (ii) ARST and LE cells average lifetime and event duration; (iii) CL and both ARST and LE major axis length, 

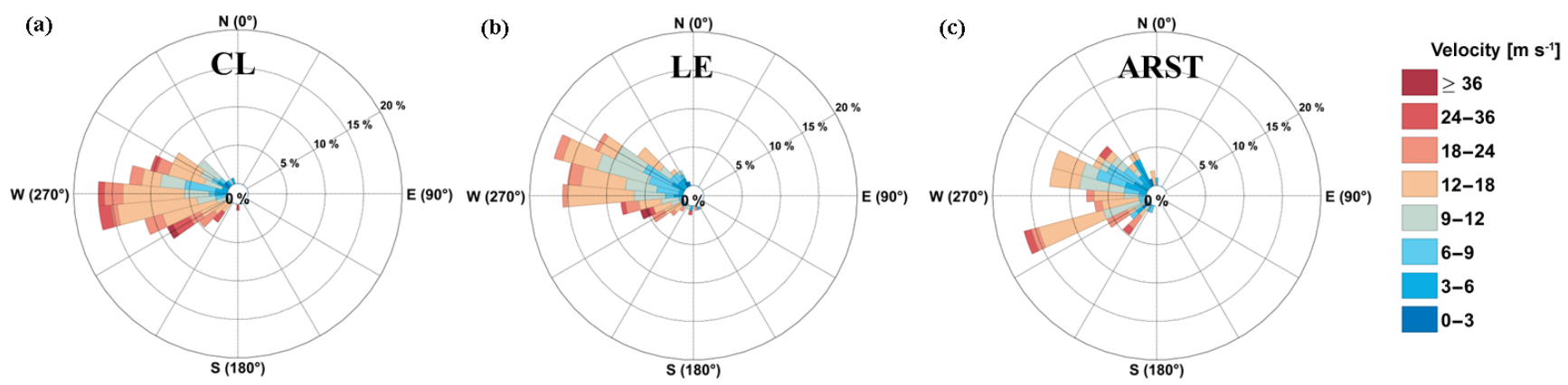

Figure 6. Advection (velocity and direction) distributions of CL (a), LE (b), and ARST (c) events.

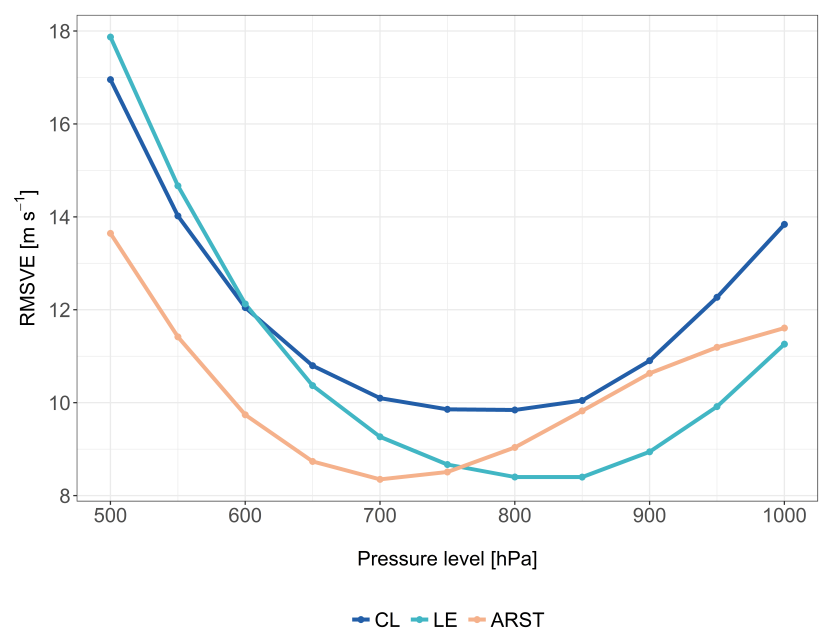

Figure 7. Calculated root mean square vector error (RMSVE) between average advection components and wind zonal and meridional components obtained from Era-Interim reanalysis for pressure levels of 500-1000 $\mathrm{hPa}$ for each synoptic system.

average direction, and average velocity of rain cells; and (iv) CL and LE cells' ellipticity. Rain cells are broadly advecting with the mean wind through some deep tropospheric layer, in which the cloud is embedded (Chappell, 1986; Doswell et al., 1996). To identify the layers that rain cells are commonly moving in over the study area, the advection vector components were compared with zonal and meridional wind components at pressure levels $500-1000 \mathrm{hPa}$ (increments of $50 \mathrm{hPa}$ ), extracted from Era-Interim reanalysis for the times closest to each rain event's mass center at a grid point closest to the center of the study area $\left(35.25^{\circ} \mathrm{E}\right.$, $31.5^{\circ} \mathrm{N}$ ). A root mean square vector error (RMSVE) was calculated for each pressure level and synoptic system (Fig. 7). The pressure levels with minimum RMSVE are in general 700 to $850 \mathrm{hPa}$, and in particular $700-850 \mathrm{hPa}$ for CL, 800$850 \mathrm{hPa}$ for LE, and around $700 \mathrm{hPa}$ for ARST.

\subsubsection{Effect of location}

The variations in rain-cell characteristics along the northsouth latitudinal gradient were examined (Fig. 8). The total number and the average cell area of the two Mediterranean lows is decreasing from north to south (Fig. 8a and b), whereas their velocity is increasing (Fig. 8c). The mean areal rain intensity of CL cells is increasing from north to south, but LE cells show an increasing trend only between latitudes 31.6 and $31.1^{\circ} \mathrm{N}$ (Fig. 8d).

A positive correlation between topographic height and cells area (Fig. 8e and b) and a negative correlation between distance from shoreline and number of cells (Fig. $8 \mathrm{f}$ and a) is seen in both Mediterranean lows in the northern part of the study area, and especially for the LE system.

The ARST rain cells follow different trends: (i) the total number of rain cells shows a smaller variation with latitude (Fig. 8a), (ii) the cells moderately increase in size along the north-south axis reaching a peak around latitudes 31.3$31.5^{\circ} \mathrm{N}$ (Fig. 8b), (iii) the cells have a moderate decrease in their velocity with latitude (Fig. 8c), and (iv) no clear trend in mean areal rain intensity is seen (Fig. 8d).

The region with higher mean annual rainfall (Fig. 8g) overlaps the regions of maximal number of cells (Fig. 8a), maximal cell area (Fig. 8b), and low velocities (Fig. 8c) of both Mediterranean lows. The region of maximal mean areal rain intensity (Fig. 8d), however, is not collocated with maximal rainfall amounts. This fits previous findings that in dryer regions rainfall is generally more intense over short durations (Marra et al., 2017; Marra and Morin, 2015).

The moderate increasing trend in velocity of Mediterranean lows' cells along the north-south axis may have resulted from a bias in favor of stronger storms in the southern part, i.e., regions that are most distant from the sea and from the Mediterranean storm tracks. Mediterranean storms that produce rainfall over those regions were most likely deep lows of stronger winds that had managed to transport clouds from the Mediterranean Sea far inland (Saaroni et al., 2010). 

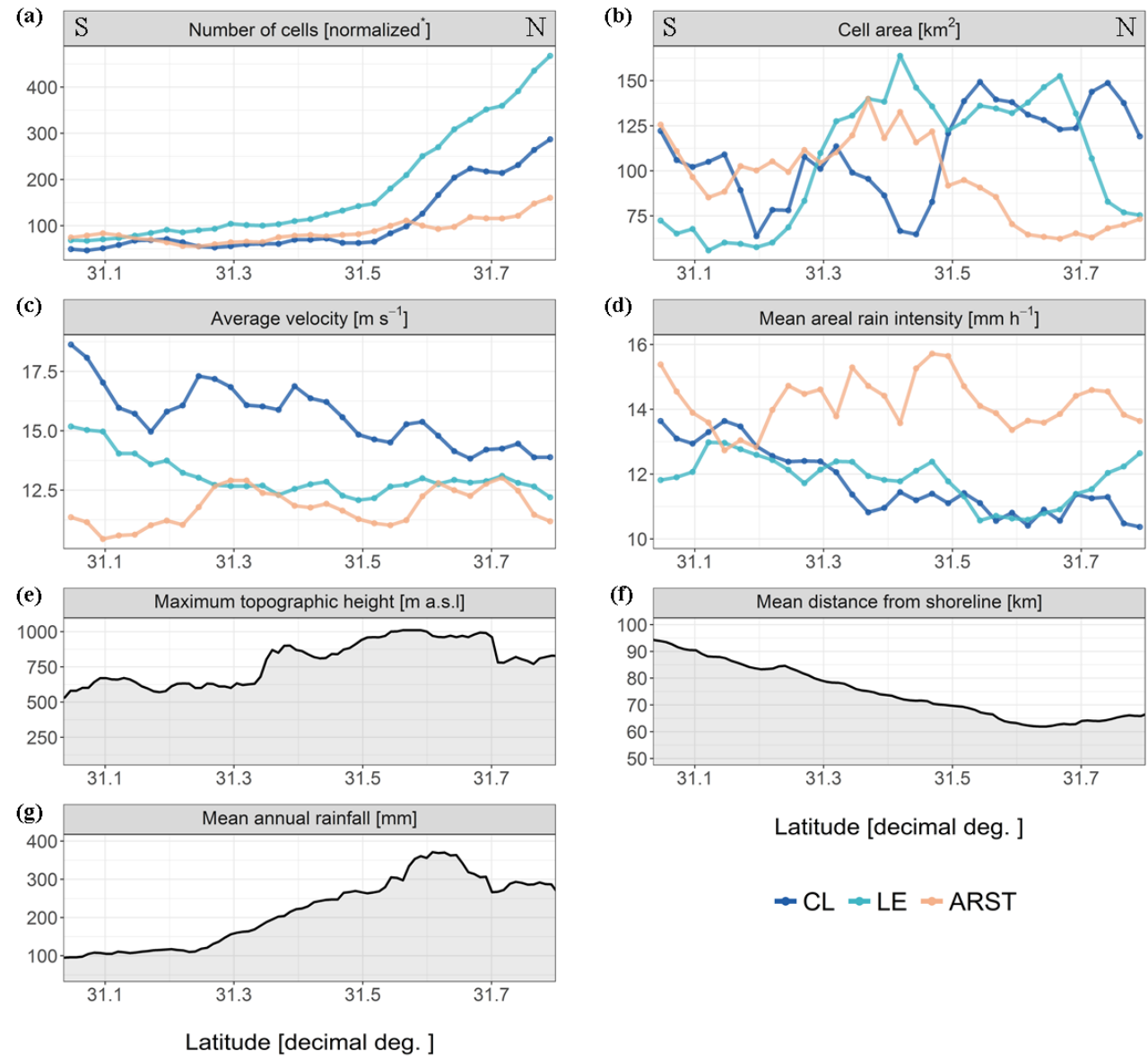

Latitude [decimal deg. ]

$\approx \mathrm{CL} \approx \mathrm{LE} \approx \mathrm{ARST}$

Figure 8. Mean rain-cell properties along a north-south (right-to-left axes) orientation of the different synoptic systems: (a) number of cells ${ }^{1}$, (b) cell area $\left(\mathrm{km}^{2}\right),(\mathbf{c})$ average velocity $\left(\mathrm{m} \mathrm{s}^{-1}\right),(\mathbf{d})$ mean areal rain intensity $\left(\mathrm{mm} \mathrm{h}^{-1}\right)$. Potentially related variables along the same axis: (e) maximal topographic height (ma.s.l.), (f) distance from shoreline $(\mathrm{km})$, and $(\mathbf{g})$ mean annual rainfall (mm). Each point represents the mean or maximal value in a west to east strip (in panels a-d, the strip is $2.5 \mathrm{~km}$ wide and a running average of $7.5 \mathrm{~km}$ is applied).

\section{Relations between rain-cell properties and flash floods}

The relationship between properties of rain cells and the occurrence and magnitude of flash floods in the Darga and Teqoa catchments (Fig. 1b) was explored. A flash flood was defined according to the criteria specified in Sect. 2.2. No distinction between the two catchments was made due to their similar morphology, and their small and narrow shape relative to an average size rain cell (Fig. 2). Out of the 424 detected rain events, 173 events had rain cells tracked above the catchments, 29 of which (532 rain cells) were associated with flash-flood events. Since the same rain event can potentially lead to a flash flood in both catchments, the 29 rain events corresponded to 41 measured flash floods (21 in Darga and 20 in Teqoa). The remaining 144 rain events (988 rain cells) were classified as "non-flash-flood" events.

Examining the event duration and total rain depth over the catchments (Fig. 9) reveal that the recorded flash floods were produced from events of a few minutes to 2 days long and areal rain depth from 1 to $100 \mathrm{~mm}$. In general, long duration and high rain depth are conditions favoring the occurrence of flash floods. A number of rain events with similar duration and depth did not lead to flash floods, confirming that short duration intensities are also important. In fact, ARST events leading to flash floods generate high peak discharges, in spite of their general shorter durations and lower rain depths than both Mediterranean lows.

Flash floods in the desert are often triggered by one or two rain cells (David-Novak et al., 2004; Yakir and Morin, 2011). In this study, the "dominant rain cell" of each event, i.e., the rain cell that contributed the largest amount of rainfall over the two catchments, was identified. The mean, median, and interquartile ranges of the properties characterizing the dominant cells of flash-flood and non-flash-flood events during their lifetime over the catchments were compared, and are presented in Fig. 10. If not stated otherwise, the results presented below are significant at 0.05 level.

\footnotetext{
${ }^{1}$ Number of cells is normalized to the relative strip area.
} 


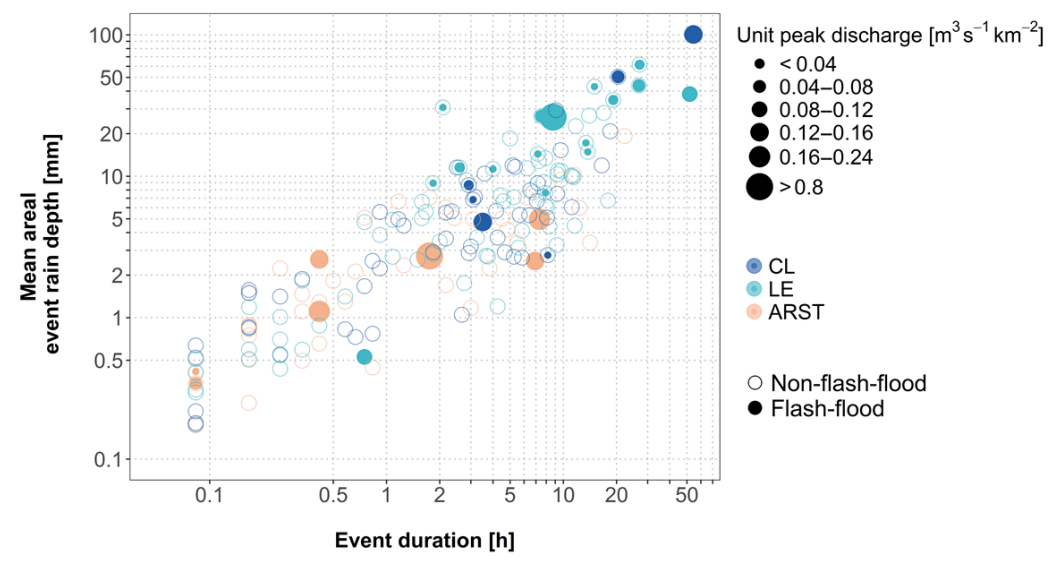

Figure 9. Scatter plot of rain events' mean areal rain depth over the catchments vs. duration, for flash-flood-associated (filled circles) and non-flash-flood events (empty circles), with respect to different synoptic types and different unit peak discharges of the flash-flood-related events. In case of flow in both catchments, maximum unit peak discharge is presented. Over $90 \%$ of the watershed area is covered by rainfall during flash-flood-related events ( $79 \%$ for the non-flash-flood-related events). Event duration refers to the part of the event where rain cells were found over the catchments.

Results show that dominant rain cells associated with flash floods are (i) larger than dominant cells not associated with flash floods ( $247 \mathrm{~km}^{2}$ compared to $159 \mathrm{~km}^{2}$; Fig. 10a) and, accordingly, cover a larger portion of the catchments area ( $77 \mathrm{~km}^{2}$ compared to $55 \mathrm{~km}^{2}$; Fig. 10b); (ii) have lower average velocities $\left(11.6 \mathrm{~m} \mathrm{~s}^{-1}\right.$ compared to $14 \mathrm{~m} \mathrm{~s}^{-1}$, significance level 0.1; Fig. 10c); and (iii) persist longer (41 min compared to $20 \mathrm{~min}$; Fig. 10d). The mean areal and maximum rain intensities of flash-flood-related dominant cells are higher than non-flash-flood dominant cells (Fig. 10g and h), though this difference was found to be not statistically significant.

Figure 11a and $\mathrm{b}$ shows the distribution of the advection of dominant cells for non-flash-flood and flash-flood events. Non-flash-flood dominant cells are generally more westerly and characterized by higher velocities $\left(14 \mathrm{~m} \mathrm{~s}^{-1}\right.$ and $275^{\circ}$, on average) than flash-flood dominant cells $\left(11.6 \mathrm{~m} \mathrm{~s}^{-1}\right.$ and $286^{\circ}$ ). Flash-flood dominant cells are characterized by a bimodal distribution with low velocity, north-northwesterly cells (generally, $<12 \mathrm{~m} \mathrm{~s}^{-1}, 300-360^{\circ}$ ) and higher velocities, westerly cells (generally, $>12 \mathrm{~m} \mathrm{~s}^{-1}, 240-300^{\circ}$ ). Considering only high magnitude flash floods (with peak discharge larger than the median) it is found that dominant rain cells are related to low velocities and north-northwesterly directions $\left(9.8 \mathrm{~m} \mathrm{~s}^{-1}\right.$ and $301^{\circ}$ on average; Fig. 11c) that match the main drainage axis of the two studied catchments (Fig. 1b).

\section{Discussion}

The properties of convective rain cells in the arid area of the Dead Sea western tributaries are discussed in relation to the governing synoptic system, location, and to flash-flood generation.

\subsection{Variation between different synoptic systems}

Rain-cell properties are distinctly associated with the characteristics of three synoptic systems governing rain events in the region: the Cyprus low, the low to the east, and the Active Red Sea Trough (CL, LE and ARST, respectively; see Sect. 3.2). ARST events have shorter duration and their rain cells are characterized by higher intensities, smaller areas, longer lifetimes, and lower velocities compared to the two Mediterranean lows. The low cell velocities are likely due to the more continental nature of this system (Goldreich et al., 2004) and to the smaller pressure gradients (Dayan et al., 2012), while the higher intensities could be related to higher surface temperatures (observed in the clustering results, not shown) leading to greater atmospheric instability (Ahrens, 2003).

The average directions of rain cells are southwest to west for CL events and west to northwest for LE events. In ARST events both modes are common. These results are explained by the location of the surface low in CL and LE systems and by the cyclonic geostrophic wind (Fig. 3); a CL located west of the study area is usually identified with southwesterly to westerly winds at low levels, while northwesterly wind directions are more dominant when the low is located at the East.

In both Mediterranean lows, southwestern cell directions are associated with higher cell velocities, while northwestern directions with lower cell velocities (Fig. 6). The lower cell velocities could be related to the slower movement of the Mediterranean low when located above land and to the larger distance of the center of the low from the study area (Fig. 3a and b). The lower average cell velocities of the LE events is therefore explained by a larger portion of northwestern cell directions. Furthermore, average cell velocity 

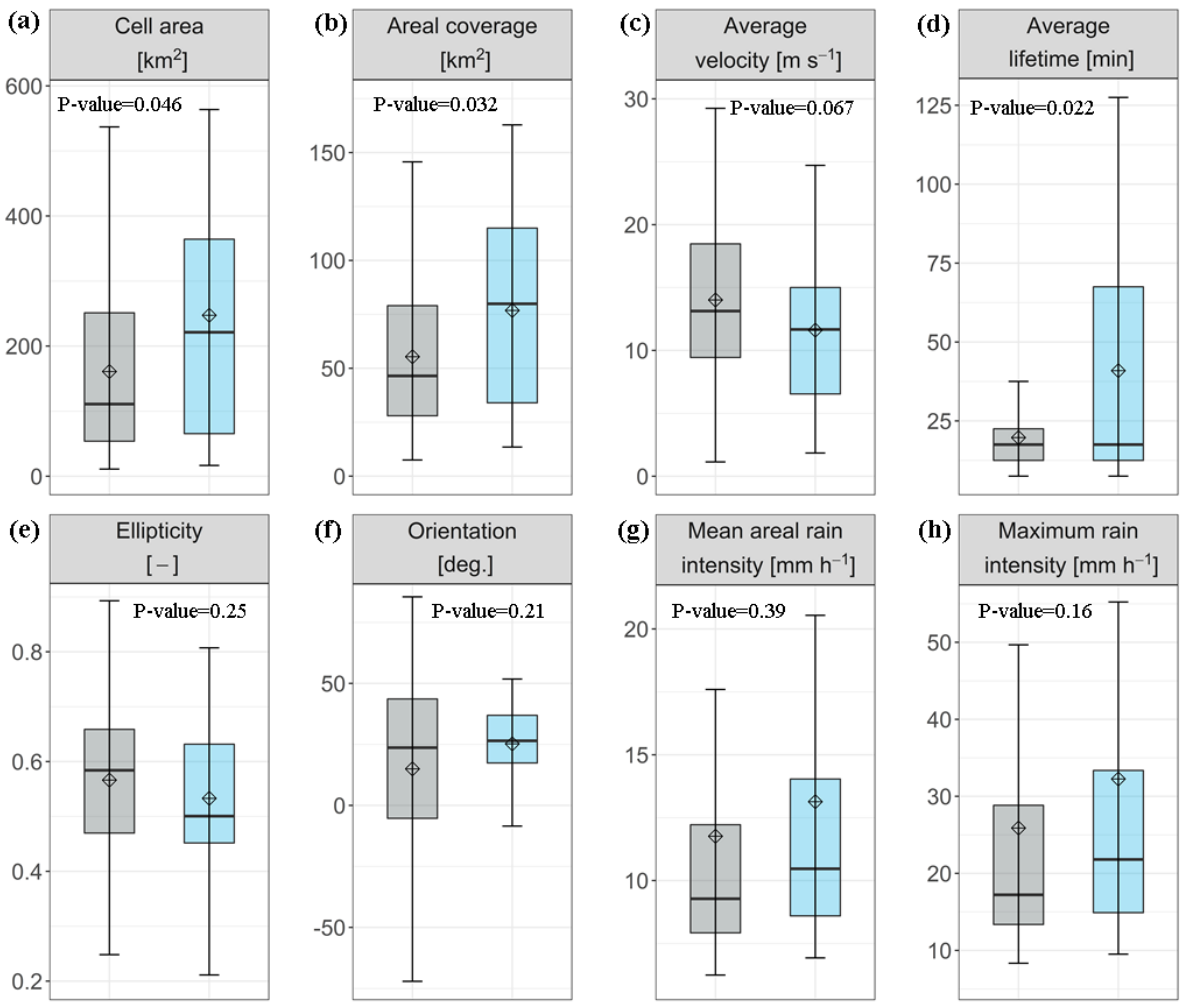

\section{追Non-flash-flood 追Flash-flood}

Figure 10. Comparison of dominant flash-flood-related cells (blue, $N=29$ ) and non-flash-flood-related cell (grey, $N=144)$ properties: (a) cell area $\left(\mathrm{km}^{2}\right),(\mathbf{b})$ areal coverage $\left(\mathrm{km}^{2}\right),(\mathbf{c})$ average velocity $\left(\mathrm{m} \mathrm{s}^{-1}\right)$, (d) average lifetime (min), (e) ellipticity, (f) orientation $\left({ }^{\circ}\right)$, (g) mean areal rain intensity $\left(\mathrm{mm} \mathrm{h}^{-1}\right)$, and $(\mathbf{h})$ maximum rain intensity $\left(\mathrm{mm} \mathrm{h}^{-1}\right)$. Values are averaged over the dominant cell's lifetime. Boxplot properties are as specified in Fig. 5. Reported $P$ values are of the ANOVA test applied between dominant flash-flood-related cells and non-flash-flood-related cells. All data sets were tested first for variance heterogeneity using Levene's test (with squared deviations). The Box-Cox transformation technique was applied to properties of unequal variances to obtain normality. In these cases, Welch's test was used.

components of Mediterranean low events are in better agreement with low level (750-850 hPa) wind components, while ARST with higher levels (700 hPa; Fig. 7). These findings agree with the synoptic understanding that ARST events are usually identified with medium-level clouds and Mediterranean lows with low-level clouds. Unlike the Mediterranean lows, which have the Mediterranean Sea as their major moisture supplier, the moisture essential for the development of convective rain cells in ARST events must be transported at the medium levels from remote southern origins, since a dry easterly wind flow is found at the lower levels (Dayan et al., 2001; Kahana et al., 2004; Krichak and Alpert, 1998).

\subsection{Variation within the study region}

Rain-cell properties vary in space. Variations along the north-south axis of the study area, characterized by a sharp decrease in mean annual rainfall (Fig. 8g), an increase in distance from the Mediterranean Sea's shoreline (Fig. 8f), and a change of topography (Fig. 8e) were examined. The rel- ative frequency of high-intensity rainfall increases with the reduction of annual rainfall amounts (Goodrich et al., 1995; Marra et al., 2017; Marra and Morin, 2015; Sharon and Kutiel, 1986), and orographic effects lead to enhanced rainfall generation (Houze, 2012; Sharon and Kutiel, 1986; Warner, 2004; Wheater et al., 1991). Both phenomena are reflected in the characteristics of the rain cells of Mediterranean lows: (i) mean rain intensities are generally increasing with the degradation of mean annual rainfall southward towards drier regions. Though the increase in rainfall intensities southward is seen explicitly in the Mediterranean lows, the increasing dominance of the ARST rain cells towards the south is likely to play a significant role in the latitudinal increase in rainfall intensities (Sharon and Kutiel, 1986); (ii) rain cells are larger where topography is higher. As stated by Goldreich et al. (2004), clouds distancing themselves from the shoreline and ascending the mountains, tend to become more uniform and continuous than over the coastal plain, thus increasing their size. When the terrain features are low enough, preexisting clouds that move over them produce maximum precipitation 

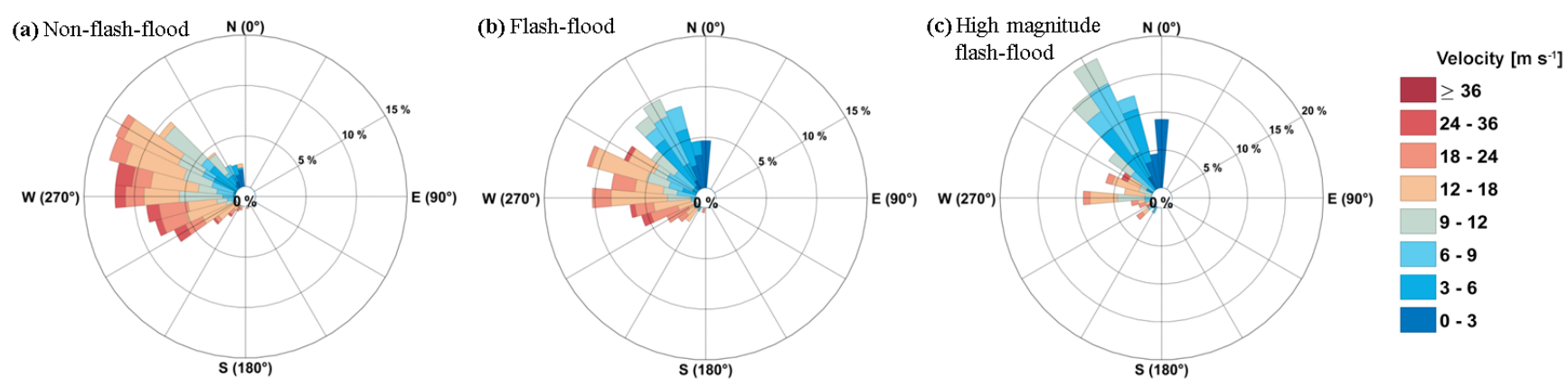

Figure 11. Advection (velocity and direction) distributions of dominant rain cells for (a) non-flash-flood events (490 cells, 144 events), (b) flash-flood events (220 cells, 29 events), and (c) high-magnitude flash-flood events (111 cells, 15 events). High magnitude is defined based on median values of measured flash floods in Darga and Teqoa used in this analysis.

on the upwind side of the barrier. As the precipitating cloud is advected to the lee side, the precipitating capacity is weakened by the downslope air motion (Houze, 2012). Our analyses included rain cells with centroids located east of the water divide, i.e., on the lee side of the mountain range (Fig. 1). Nevertheless, in many cases the cell area includes precipitation also on the west side of the water divide and thus the total effect obtained is the cell area increase along with the rain intensity weakening over the mountainous areas.

\subsection{Flash-flood-related characteristics}

A few studies had focused on the contribution of the spatial and temporal characteristics of rain cells to flash-flood generation in arid environments. Doswell et al. (1996) reported that slow storm velocities contribute to flash-flood generation and Syed et al. (2003) underlined the importance of the areal coverage of the storm core for runoff generation in a semiarid catchment. Bracken et al. (2008) suggested that floods, though mainly related to the total rainfall, were eventually triggered by intense bursts of rain. Our results support these previous findings, showing that flash-flood-related and nonflash-flood-related rain cells differ in size, areal coverage, velocity, lifetime over the catchment, and rain intensity.

Other studies wished to analyze the impact of the spatial and temporal characteristics of rain cells on flash-flood magnitude by using case studies of real storms (Smith et al., 2010; Yang et al., 2016a) or model simulations (Morin et al., 2006; Rozalis et al., 2010; Wright et al., 2014; Yakir and Morin, 2011; Yang et al., 2016b). While some argued about the importance of rainfall intensity distribution (Chang, 2007; Rozalis et al., 2010; Yang et al., 2016b), a common conclusion concerned the movement of the storm: slower storms directed downstream of the catchment seem to produce flash floods of higher magnitudes (Doswell et al., 1996; Singh, 1997; Smith et al., 2000; Yakir and Morin, 2011). Our results confirm this effect: rain cells moving downstream with a direction close to the orientation of the principal axis of the catchments (Fig. 1) at low average velocities $\left(<12 \mathrm{~m} \mathrm{~s}^{-1}\right)$ are related to higher peak discharges.

Due to the small sample of flash-flood events (29 events), the influence of the synoptic type on flash-flood generation was not taken into consideration. Nevertheless, results presented in Sect. 3 suggest that ARST rain cells should have larger flash-flooding potential, due to the lower velocities, longer lifetime, and higher intensities; for example, $55 \%$ of the ARST rain cells analyzed had velocities lower than $12 \mathrm{~m} \mathrm{~s}^{-1}$ ) against only 33 and $46 \%$ for CL and LE. Out of them, the fraction with mean areal rain intensities higher than $10 \mathrm{~mm} \mathrm{~h}^{-1}$ ) are 63,39 , and $46 \%$ for ARST, CL, and LE cells, respectively. In fact, 6 out of the 7 flash floods generated by ARST events were characterized by high magnitude. Other studies underlined the localized and intense nature of ARST storms and their high flash-flooding potential (Dayan et al., 2001; Kahana et al., 2002; Ziv et al., 2004).

Some of the rain-cell properties associated with flash floods are tied with the catchment properties. For example, large catchments might be less influenced by ARST rain cells due to their smaller size. The more northwesterly cell directions associated with LE events and part of the ARST events might present better flooding conditions relative to other cell directions, due to the northwest to southeast orientation $\left(\sim 315^{\circ}\right)$ of the Darga and Teqoa catchments (Fig. 1), but might not have any advantage in the case of a different catchment orientation. This seems to be reflected in the increased representation of LE in flash-flood-related events in Darga and Teqoa (55\%) in comparison with the general frequency of LE events in the entire study area (44\%). Furthermore, Kahana et al. (2002) found that the frequency of flash floods in the Negev (south of our study area) generated by ARST events is slightly higher (38\% in comparison with $24 \%$ found in our study) than Syrian low events (33\%), which are most likely the equivalent to our LE events. These differences may arise from the different sample sets analyzed by Kahana et al. (2002) (only floods $>5$ years recurrence interval were taken) and from the more northeastern location of the Dead Sea region than the Negev, and may indicate the 
importance of the LE events in generating flash floods in the Dead Sea region, especially in the northern parts of our study area.

\section{Conclusions}

This study provides a climatology of spatial and temporal properties of radar-derived convective rain cells over the dry area of the Dead Sea (Eastern Mediterranean region). These properties are examined in relation to the governing synoptic system and to flash-flood generation and magnitude. The study offers a statistical approach to relate rainfall properties (e.g., the properties of the most contributing cell) to catchment response. The main findings of the study are as follows:

- Convective rain cells are on average $92 \mathrm{~km}^{2}$ in size, move at a velocity of $12.8 \mathrm{~m} \mathrm{~s}^{-1}$ from west to east, and live for $18.1 \mathrm{~min}$.

- ARST events are characterized by the shortest event duration, highest cell mean areal rain intensity, smallest cell area, longest cell lifetime, and lowest cell velocity.

- The area of rain cells generated by Mediterranean lows is positively correlated with the topographic height in the northern part of the study area, the number of cells is negatively correlated with the distance from the shoreline, and the mean rain intensities are negatively correlated with mean annual rainfall.

- High mean annual rainfall in the northern mountainous part of the study area results from a large number of rain cells with low velocities and large area rather than cells of high rain intensities. Rain cells related to flash-flood events are characterized by larger area, lower velocity, and longer lifetime over the catchment.

- Rain cells with lower velocities (generally $<12 \mathrm{~m} \mathrm{~s}^{-1}$ ) and of north to northwestern origins, directed downstream with the main catchment axis, lead to high magnitude flash floods.

Results from this study add insights and quantitative information to previous studies in the Dead Sea region and in other arid regions worldwide. This advocates the robustness of the methods applied and the adequacy of the radar data used to represent rainfall over the study area. The distributions of the convective rain-cell characteristics extracted in this work can be used for stochastic simulations of convective rain storms and serve as input for hydrological models and for flash-flood nowcasting systems.

Data availability. Rainfall data from a C-band weather radar were provided by the company E.M.S. Mekorot for exclusive use and elaborated by Marra and Morin (2015). Streamflow data were provided by the Israel Hydrological Service, and are available upon request: http://www.water.gov.il/Hebrew/ ProfessionalInfoAndData/Pages/default.aspx. Atmospheric variables extracted from the ERA-Interim reanalysis (Dee et al., 2011) are available at the following link: http://apps.ecmwf.int/datasets/ data/interim-full-daily.

Competing interests. The authors declare that they have no conflict of interest.

Special issue statement. This article is part of the special issue "Environmental changes and hazards in the Dead Sea region (NHESS/ACP/HESS/SE inter-journal SI)". It is not associated with a conference.

Acknowledgements. The study was partially funded by the Dead Sea Drainage Authority, the Israel Water Authority, the Israel Science Foundation (grant no. 1007/15), the NSF-BSF grant (BSF 2016953) and the Lady Davis Fellowship Trust (project: RainFreq). This work is a contribution to the HyMeX program. The authors thank Maya Bartov, Moshe Armon and Uri Dayan for their assistance in validating the automatic classification of the synoptic systems.

Edited by: Florian Pappenberger

Reviewed by: two anonymous referees

\section{References}

Ahrens, C. D.: Meteorology today: an introduction to weather, climate, and the environment, Brooks/Cole-Thomson Learning, 7th Edn., 2003.

Alpert, P., Osetinsky, I., Ziv, B., and Shafir, H.: Semi-objective classification for daily synoptic systems: application to the eastern Mediterranean climate change, Int. J. Climatol., 24, 1001-1011, https://doi.org/10.1002/joc.1036, 2004.

Andréassian, V., Oddos, A., Michel, C., Anctil, F., Perrin, C., and Loumagne, C.: Impact of spatial aggregation of inputs and parameters on the efficiency of rainfall-runoff models: A theoretical study using chimera watersheds, Water Resour. Res., 40, W05209, https://doi.org/10.1029/2003WR002854, 2004.

Ashbel, D.: Great floods in Sinai Peninsula, Palestine, Syria and the Syrian Desert, and the influence of the red sea on their formation, Q. J. Roy. Meteor. Soc., 64, 635-639, https://doi.org/10.1002/qj.49706427716, 1938.

Bahat, Y., Grodek, T., Lekach, J., and Morin, E.: Rainfall-runoff modeling in a small hyper-arid catchment, J. Hydrol., 373, 204217, https://doi.org/10.1016/j.jhydrol.2009.04.026, 2009.

Barnolas, M., Rigo, T., and Llasat, M. C.: Characteristics of 2-D convective structures in Catalonia (NE Spain): an analysis using radar data and GIS, Hydrol. Earth Syst. Sci., 14, 129-139, https://doi.org/10.5194/hess-14-129-2010, 2010.

Berne, A. and Krajewski, W. F.: Radar for hydrology: Unfulfilled promise or unrecognized potential?, Adv. Water Resour., 51, 357-366, https://doi.org/10.1016/j.advwatres.2012.05.005, 2013. 
Borga, M., Anagnostou, E. N., Blöschl, G., and Creutin, J. D.: Flash flood forecasting, warning and risk management: The HYDRATE project, Environ. Sci. Pol., 14, 834-844, https://doi.org/10.1016/j.envsci.2011.05.017, 2011.

Borga, M., Stoffel, M., Marchi, L., Marra, F., and Jakob, M.: Hydrogeomorphic response to extreme rainfall in headwater systems: Flash floods and debris flows, J. Hydrol., 518, 194-205, https://doi.org/10.1016/j.jhydrol.2014.05.022, 2014.

Bracken, L. J., Cox, N. J., and Shannon, J.: The relationship between rainfall inputs and flood generation in south-east Spain, Hydrol. Process., 22, 683-696, https://doi.org/10.1002/hyp.6641, 2008.

Cannon, A. J., Whitfield, P. H., and Lord, E. R.: Synoptic map-pattern classification using recursive partitioning and principal component analysis, Mon. Weather Rev., 130, 1187-1206, https://doi.org/10.1175/15200493(2002)130<1187:SMPCUR>2.0.CO;2, 2002.

Chang, C.-L.: Influence of Moving Rainstorms on Watershed Responses, Environ. Eng. Sci., 24, 1353-1360, https://doi.org/10.1089/ees.2006.0220, 2007.

Chappell, C. F.: Quasi-Stationary Convective Events, 289310, American Meteorological Society, Boston, MA, https://doi.org/10.1007/978-1-935704-20-1_13, 1986.

Cox, D. R. and Isham, V.: A Simple Spatial-Temporal Model of Rainfall, P. R. Soc. Lond. A Mat., 415, 317-328, 1988.

David-Novak, H. B., Morin, E., and Enzel, Y.: Modern extreme storms and the rainfall thresholds for initiating debris flow on the hyperarid western escarpment of the Dead Sea, Israel, B. Geol. Soc. Am., 116, 718-728, https://doi.org/10.1130/B25403.2, 2004.

Dayan, U. and Morin, E.: Flash flood-producing rainstorms over the Dead Sea: A review, Geol. Soc. Am. S., 401, 53-62, https://doi.org/10.1130/2006.2401(04), 2006.

Dayan, U., Ziv, B., Margalit, A., Morin, E., and Sharon, D.: A severe autumn storm over the Middle-East: Synoptic and mesoscale convection analysis, Theor. Appl. Climatol., 69, 103122, https://doi.org/10.1007/s007040170038, 2001.

Dayan, U., Tubi, A., and Levy, I.: On the importance of synoptic classification methods with respect to environmental phenomena, Int. J. Climatol., 32, 681-694, https://doi.org/10.1002/joc.2297, 2012.

Dayan, U., Nissen, K., and Ulbrich, U.: Review Article: Atmospheric conditions inducing extreme precipitation over the eastern and western Mediterranean, Nat. Hazards Earth Syst. Sci., 15, 2525-2544, https://doi.org/10.5194/nhess-15-2525-2015, 2015.

Dee, D. P., Uppala, S. M., Simmons, A. J., Berrisford, P., Poli, P., Kobayashi, S., Andrae, U., Balmaseda, M. A., Balsamo, G., and Bauer, P.: The ERA-Interim reanalysis: Configuration and performance of the data assimilation system, Q. J. Roy. Meteor. Soc., 137, 553-597, https://doi.org/10.1002/qj.828, 2011.

Dixon, M. and Wiener, G.: TITAN: Thunderstorm Identification, Tracking, Analysis, and Nowcasting - A Radarbased Methodology, 10, 785-797, https://doi.org/10.1175/15200426(1993)010<0785:TTITAA>2.0.CO;2, 1993.

Doswell, C. A., Brooks, H. E., and Maddox, R. A.: Flash Flood Forecasting: An Ingredients-Based Methodology, Weather Forecast., 11, 560-581, https://doi.org/10.1175/15200434(1996)011<0560:FFFAIB>2.0.CO;2, 1996.
Faurés, J.-M., Goodrich, D. C., Woolhiser, D. A., and Sorooshian, S.: Impact of small-scale spatial rainfall variability on runoff modeling, J. Hydrol., 173, 309-326, https://doi.org/10.1016/0022-1694(95)02704-S, 1995.

Féral, L.: HYCELL - A new hybrid model of the rain horizontal distribution for propagation studies: 2. Statistical modeling of the rain rate field, Radio Sci., 38, 1-18, https://doi.org/10.1029/2002RS002803, 2003.

Féral, L., Mesnard, F., Sauvageot, H., Castanet, L., and Lemorton, J.: Rain Cells Shape and Orientation Distribution in South-West of France, 25, 1073-1078, 2000.

Goldreich, Y.: The Climate of Israel: Observation, Research and Application, Kluwer Acad., New York, 2003.

Goldreich, Y., Mozes, H., and Rosenfeld, D.: Radar Analysis of Cloud Systems and Their Rainfall Yield in Israel, Isr. J. Earth Sci., 53, 63-76, https://doi.org/10.1560/G68K-30MND5V0-KUHU, 2004.

Goodrich, D. C., Faurés, J.-M., Woolhiser, D. A., Lane, L. J., and Sorooshian, S.: Measurement and analysis of small-scale convective storm rainfall variability, J. Hydrol., 173, 283-308, https://doi.org/10.1016/0022-1694(95)02703-R, 1995.

Greenbaum, N., Ben-Zvi, A., Haviv, I., and Enzel, Y.: The hydrology and paleohydrology of the Dead Sea tributaries, Geol. Soc. Am. S., 401, 63-93, https://doi.org/10.1130/2006.2401(05), 2006.

Hewitson, B. C. and Crane, R. G.: Self-orginizing maps, Application to synoptic climatology, Clim. Res., 22, 13-26, https://doi.org/10.3354/cr022013, 2002.

Houze, R.: Orographic Effects on Precipitating Clouds, Rev. Geophys., 50, RG1001, https://doi.org/10.1029/2011RG000365, 2012.

Johnson, J. T., MacKeen, P. L., Witt, A., Mitchell, E. D. W., Stumpf, G. J., Eilts, M. D., and Thomas, K. W.: The Storm Cell Identification and Tracking Algorithm: An Enhanced WSR-88D Algorithm, Weather Forecast., 13, 263-276, https://doi.org/10.1175/15200434(1998)013<0263:TSCIAT>2.0.CO;2, 1998.

Kahana, R., Ziv, B., Enzel, Y., and Dayan, U.: Synoptic climatology of major floods in the Negev Desert, Israel, Int. J. Climatol., 22, 867-882, https://doi.org/10.1002/joc.766, 2002.

Kahana, R., Ziv, B., Dayan, U., and Enzel, Y.: Atmospheric predictors for major floods in the Negev Desert, Israel, Int. J. Climatol., 24, 1137-1147, https://doi.org/10.1002/joc.1056, 2004.

Karklinsky, M. and Morin, E.: Spatial characteristics of radarderived convective rain cells over southern Israel, Meteorol. Z., 15, 513-520, https://doi.org/10.1127/0941-2948/2006/0153, 2006.

Krajewski, W. and Smith, J.: Radar hydrology: rainfall estimation, Adv. Water Resour., 25, 1387-1394, https://doi.org/10.1016/S0309-1708(02)00062-3, 2002.

Krichak, S. O. and Alpert, P.: Role of large scale moist dynamics in November 1-5, 1994, hazardous Mediterranean weather, J. Geophys. Res., 103, 19453-19468, 1998.

Kyznarová, H. and Novák, P.: CELLTRACK - Convective cell tracking algorithm and its use for deriving life cycle characteristics, Atmos. Res., 93, 317-327, https://doi.org/10.1016/j.atmosres.2008.09.019, 2009.

Llasat, M. C., Llasat-Botija, M., Prat, M. A., Porcú, F., Price, C., Mugnai, A., Lagouvardos, K., Kotroni, V., Katsanos, D., 
Michaelides, S., Yair, Y., Savvidou, K., and Nicolaides, K.: High-impact floods and flash floods in Mediterranean countries: the FLASH preliminary database, Adv. Geosci., 23, 47-55, https://doi.org/10.5194/adgeo-23-47-2010, 2010.

Marra, F. and Morin, E.: Use of radar QPE for the derivation of Intensity-Duration-Frequency curves in a range of climatic regimes, J. Hydrol., 531, 427-440, https://doi.org/10.1016/j.jhydrol.2015.08.064, 2015.

Marra, F., Morin, E., Peleg, N., Mei, Y., and Anagnostou, E. N.: Intensity-duration-frequency curves from remote sensing rainfall estimates: comparing satellite and weather radar over the eastern Mediterranean, Hydrol. Earth Syst. Sci., 21, 2389-2404, https://doi.org/10.5194/hess-21-2389-2017, 2017.

Morin, E. and Gabella, M.: Radar-based quantitative precipitation estimation over Mediterranean and dry climate regimes, J. Geophys. Res., 112, D20108, https://doi.org/10.1029/2006JD008206, 2007.

Morin, E. and Yakir, H.: Hydrological impact and potential flooding of convective rain cells in a semiarid environment, Hydrolog. Sci. J., 59, 1353-1362, https://doi.org/10.1080/02626667.2013.841315, 2014.

Morin, E., Enzel, Y., Shamir, U., and Garti, R.: The characteristic time scale for basin hydrological response using radar data, J. Hydrol., 252, 85-99, https://doi.org/10.1016/S00221694(01)00451-6, 2001.

Morin, E., Goodrich, D. C., Maddox, R. a., Gao, X., Gupta, H. V., and Sorooshian, S.: Spatial patterns in thunderstorm rainfall events and their coupling with watershed hydrological response, Adv. Water Resour., 29, 843-860, https://doi.org/10.1016/j.advwatres.2005.07.014, 2006.

Morin, E., Jacoby, Y., Navon, S., and Bet-Halachmi, E.: Towards flash-flood prediction in the dry Dead Sea region utilizing radar rainfall information, Adv. Water Resour., 32, 1066-1076, https://doi.org/10.1016/j.advwatres.2008.11.011, 2009.

Nied, M., Pardowitz, T., Nissen, K., Ulbrich, U., Hundecha, Y., and Merz, B.: On the relationship between hydrometeorological patterns and flood types, J. Hydrol., 519, 32493262, https://doi.org/10.1016/j.jhydrol.2014.09.089, 2014.

Northrop, P.: A clustered spatial-temporal model of rainfall, 454, 1875-1888, https://doi.org/10.1098/rspa.1998.0238, 1997.

Peleg, N. and Morin, E.: Convective rain cells: Radar-derived spatiotemporal characteristics and synoptic patterns over the eastern Mediterranean, J. Geophys. Res., 117, D15116, https://doi.org/10.1029/2011JD017353, 2012.

Peleg, N., Ben-Asher, M., and Morin, E.: Radar subpixel-scale rainfall variability and uncertainty: lessons learned from observations of a dense rain-gauge network, Hydrol. Earth Syst. Sci., 17, 2195-2208, https://doi.org/10.5194/hess-17-2195-2013, 2013.

Peleg, N., Bartov, M., and Morin, E.: CMIP5-predicted climate shifts over the East Mediterranean: implications for the transition region between Mediterranean and semi-arid climates, Int. J. Climatol., 35, 2144-2153, https://doi.org/10.1002/joc.4114, 2015a.

Peleg, N., Shamir, E., Georgakakos, K. P., and Morin, E.: A framework for assessing hydrological regime sensitivity to climate change in a convective rainfall environment: a case study of two medium-sized eastern Mediterranean catchments, Israel, Hydrol. Earth Syst. Sci., 19, 567-581, https://doi.org/10.5194/hess-19567-2015, 2015b.
Peleg, N., Marra, F., Fatichi, S., Paschalis, A., Molnar, P., and Burlando, P.: Spatial variability of extreme rainfall at radar subpixel scale, J. Hydrol., https://doi.org/10.1016/j.jhydrol.2016.05.033, online first, 2016.

Ries, F., Schmidt, S., Sauter, M., and Lange, J.: Controls on runoff generation along a steep climatic gradient in the Eastern Mediterranean, J. Hydrol.: Regional Studies, 9, 18-33, https://doi.org/10.1016/j.ejrh.2016.11.001, 2017.

Rinehart, R. E. and Garvey, E. T.: Three-dimensional storm motion detection by conventional weather radar, 273, 287-289, https://doi.org/10.1038/273287a0, 1978.

Rozalis, S., Morin, E., Yair, Y., and Price, C.: Flash flood prediction using an uncalibrated hydrological model and radar rainfall data in a Mediterranean watershed under changing hydrological conditions, J. Hydrol., 394, 245-255, https://doi.org/10.1016/j.jhydrol.2010.03.021, 2010.

Saaroni, H., Halfon, N., Ziv, B., Alpert, P., and Kutiel, H.: Links between the rainfall regime in Israel and location and intensity of Cyprus lows, Int. J. Climatol., 30, 1014-1025, https://doi.org/10.1002/joc.1912, 2010.

Saaroni, H., Ziv, B., Lempert, J., Gazit, Y., and Morin, E.: Prolonged dry spells in the Levant region: Climatologicsynoptic analysis, International J. Climatol., 2236, 2223-2236, https://doi.org/10.1002/joc.4143, 2014.

Segond, M. L., Wheater, H. S., and Onof, C.: The significance of spatial rainfall representation for flood runoff estimation: A numerical evaluation based on the Lee catchment, UK, J. Hydrol., 347, 116-131, https://doi.org/10.1016/j.jhydrol.2007.09.040, 2007.

Shamir, E., Ben-Moshe, L., Ronen, A., Grodek, T., Enzel, Y., Georgakakos, K. P., and Morin, E.: Geomorphology-based index for detecting minimal flood stages in arid alluvial streams, Hydrol. Earth Syst. Sci., 17, 1021-1034, https://doi.org/10.5194/hess-171021-2013, 2013.

Sharon, D. and Kutiel, H.: The distribution of rainfall intensity in Israel, its regional and seasonal variations and its climatological evaluation, J. Climatol., 6, 277-291, https://doi.org/10.1002/joc.3370060304, 1986.

Singh, V. P.: Effect of spatial and temporal variability in rainfall and watershed characteristics on stream flow hydrograph, Hydrol. Process., 11, 1649-1669, https://doi.org/10.1002/(SICI)10991085(19971015)11:12<1649::AID-HYP495>3.0.CO;2-1, 1997.

Smith, J. a., Baeck, M. L., Morrison, J. E., and SturdevantRees, P.: Catastrophic Rainfall and Flooding in Texas, J. Hydrometeorol., 1, 5-25, https://doi.org/10.1175/15257541(2000)001<0005:CRAFIT>2.0.CO;2, 2000.

Smith, J. A., Baeck, M. L., Morrison, J. E., Sturdevant-Rees, P., Turner-Gillespie, D. F., and Bates, P. D.: The Regional Hydrology of Extreme Floods in an Urbanizing Drainage Basin, J. Hydrometeorol., 3, 267-282, https://doi.org/10.1175/15257541(2002)003<0267:TRHOEF>2.0.CO;2, 2002.

Smith, J. a., Baeck, M. L., Villarini, G., and Krajewski, W. F.: The Hydrology and Hydrometeorology of Flooding in the Delaware River Basin, J. Hydrometeorol., 11, 841-859, https://doi.org/10.1175/2010JHM1236.1, 2010.

Steiner, M., Houze, R. A., and Yuter, S. E.: Climatological Characterization of Three-Dimensional Storm Structure from Operational Radar and Rain Gauge 
Data, 34, 1978-2007, https://doi.org/10.1175/15200450(1995)034<1978:CCOTDS>2.0.CO;2, 1995.

Syed, K. H., Goodrich, D. C., Myers, D. E., and Sorooshian, S.: Spatial characteristics of thunderstorm rainfall fields and their relation to runoff, J. Hydrol., 271, 1-21, https://doi.org/10.1016/S0022-1694(02)00311-6, 2003.

Tarolli, P., Borga, M., Morin, E., and Delrieu, G.: Analysis of flash flood regimes in the North-Western and South-Eastern Mediterranean regions, Nat. Hazards Earth Syst. Sci., 12, 1255-1265, https://doi.org/10.5194/nhess-12-1255-2012, 2012.

Tubi, A. and Dayan, U.: Tropical Plumes over the Middle East: Climatology and synoptic conditions, Atmos. Res., 145-146, 168181, https://doi.org/10.1016/j.atmosres.2014.03.028, 2014.

von Hardenberg, J.: The shape of convective rain cells, Geophys. Res. Lett., 30, 4-7, https://doi.org/10.1029/2003GL018539, 2003.

Warner, T. T.: Desert Meteorology, 61, 89-90, https://doi.org/10.1256/wea.201.04, 2004.

Wheater, H. S., Butler, A. P., Stewart, E. J., and Hamilton, G. S.: A multivariate spatial-temporal model of rainfall in southwest Saudi Arabia. I. Spatial rainfall characteristics and model formulation, J. Hydrol., 125, 175-199, https://doi.org/10.1016/00221694(91)90028-G, 1991.

Wheater, H. S., Isham, V. S., Cox, D. R., Chandler, R. E., Kakou, A., Northrop, P. J., Oh, L., Onof, C., and Rodriguez-Iturbe, I.: Spatial-temporal rainfall fields: modelling and statistical aspects, Hydrol. Earth Syst. Sci., 4, 581-601, https://doi.org/10.5194/hess-4-581-2000, 2000.

Wright, D., Smith, J., and Baeck, M.: Flood frequency analysis using radar rainfall fields and stochastic storm transposition, Water Resour. Res., 50, 1592-1615, https://doi.org/10.1002/2013WR014224, 2014.

Yair, A. and Lavee H.: Runoff Generation in arid and semi-arid zones, in: Hydrological Forecasting, edited by: Anderson, M. G. and Burt, T. P., Wiley, Chichester, UK, 183-220, 1985.

Yakir, H. and Morin, E.: Hydrologic response of a semi-arid watershed to spatial and temporal characteristics of convective rain cells, Hydrol. Earth Syst. Sci., 15, 393-404, https://doi.org/10.5194/hess-15-393-2011, 2011.
Yang, L., Smith, J., Baeck, M. L., Smith, B., Tian, F., and Niyogi, D.: Structure and evolution of flash flood producing storms in a small urban watershed, J. Geophys. Res.-Atmos., 121, 31393152, https://doi.org/10.1002/2015JD024478, 2016a.

Yang, L., Smith, J., Baeck, M. L., and Zhang, Y.: Flash flooding in small urban watersheds: Stormevent hydrologic response, Water Resour. Res., 52, 4571-4589, https://doi.org/10.1002/2015WR018326, 2016b.

Zangvil, A. and Druian, P.: Upper air trough axis orientation and the spatial distribution of rainfall over Israel, Int. J. Climatol., 10, 57-62, 1990.

Zangvil, A., Karas, S., and Sasson, A.: Connection between Eastern Mediterranean seasonal mean $500 \mathrm{hPa}$ height and sea-level pressure patterns and the spatial rainfall distribution over Israel, Int. J. Climatol., 23, 1567-1576, https://doi.org/10.1002/joc.955, 2003.

Ziv, B.: A subtropical rainstorm associated with a tropical plume over Africa and the Middle-East, Theor. Appl. Climatol., 69, 91102, https://doi.org/10.1007/s007040170037, 2001.

Ziv, B., Dayan, U., and Sharon, D.: A mid-winter, tropical extreme flood-producing storm in southern Israel: Synoptic scale analysis, Meteorol. Atmos. Phys., 88, 53-63, https://doi.org/10.1007/s00703-003-0054-7, 2004.

Ziv, B., Dayan, U., Kushnir, Y., Roth, C., and Enzel, Y.: Regional and global atmospheric patterns governing rainfall in the southern Levant, Int. J. Climatol., 26, 55-73, https://doi.org/10.1002/joc.1238, 2006.

Zoccatelli, D., Borga, M., Zanon, F., Antonescu, B., and Stancalie, G.: Which rainfall spatial information for flash flood response modelling? A numerical investigation based on data from the Carpathian range, Romania, J. Hydrol., 394, 148-161, https://doi.org/10.1016/j.jhydrol.2010.07.019, 2010. 